\title{
Clinical and Hemodynamic Characteristics of Double Chambered Right Ventricle in Adult Patients
}

\author{
Vishwanath Hesarur* and Prabhakar Kore \\ Department of Cardiology, Jawaharlal Nehru Medical College, KLE Academy of Higher Education and Research, India
}

Submission: December 21, 2017; Published: February 09, 2018

*Corresponding author: Vishwanath Hesarur, Department of Cardiology, Jawaharlal Nehru Medical College, KLE Academy of Higher Education and Research, Belagavi, Karnataka, India, Tel: +919480008361; Email: drvishwanathhesarur@yahoo.com

\begin{abstract}
Introduction: Double chambered right ventricle (DCRV) is a rare congenital anomaly in which right ventricle (RV) is divided into two chambers by anomalous muscle band (AMB), a proximal high-pressure and distal low pressure chamber. Most of DCRV cases present during childhood, however, less commonly manifest in adulthood because of the nonspecific nature of symptoms leading to a delayed diagnosis However, there are very few studies of DCRV in adults with regard to clinical features, hemodynamic data, treatment and prognosis, hence these are assessed in this current study.
\end{abstract}

Methods: A total of 10 adult patients (age $\geq 18$ years) diagnosed as DCRV by echocardiograpy and cardiac catheterization in our hospital from January 2008 to December 2015 were included. Nine patients had a history of a known heart disease since childhood (PM-VSD) with one patient being operated at the age 9 years and one patient had isolated DCRV. Nine patients underwent surgery. Their follow-up echocardiogram showed the pressure gradient in their right ventricle was significantly decreased from $63.5 \pm 14.1 \mathrm{mmHg}$ preoperatively to $10.0 \pm 5.0 \mathrm{mmHg}$ postoperatively $(\mathrm{p}<0.05)$

Conclusion: DCRV has been reported as a rare disease in adults. Consequently, number of cases are missed and not diagnosed. Careful evaluation of DCRV by echocardiography including TEE is necessary, especially in patients with VSD. These patients should be treated surgically, because the obstruction is progressive and ends in heart failure.

Keywords: Double chambered right ventricle; Congenital; Ventricular septal defect; Echocardiography; Anomalous muscle band; Cardiac catheterization; Right ventricular outflow tract

\section{Introduction}

Double chambered right ventricle (DCRV) is a rare congenital anomaly in which right ventricle (RV) is divided into two chambers by anomalous muscle band (AMB), a proximal high-pressure and distal low pressure chamber. It is seen in only $0.5-2 \%$ of all cases of congenital heart disease [1]. Most of DCRV cases present during childhood, however, less commonly manifest in adulthood because of the nonspecific nature of symptoms leading to a delayed diagnosis [2]. If identified in childhood, this condition should be adequately treated otherwise the Right ventricular outflow tract (RVOT) obstruction tends to progress and eventually lead to the patients becoming symptomatic. It is commonly associated with other congenital anomalies, most frequently peri-membranous ventricular septal defect (PM-VSD) [3,4]. However, there are very few studies of DCRV in adults with regard to clinical features, hemodynamic data, treatment and prognosis, hence these are assessed in this current study.

\section{Methods}

A total of 10 adult patients (age $\geq 18$ years) diagnosed as DCRV by echocardiograpy and cardiac catheterization in our hospital from January 2008 to December 2015 were included. Diagnosis of DCRV was based on the following criteria [5]:

a) A pressure gradient by echocardiogram or cardiac catheterization across the AMB within the right ventricle.

b) Angiographic demonstration of anomalous obstruction within the right ventricle.

c) Absence of infundibular hypoplasia and

d) Surgical confirmation of DCRV in the operating room

Two dimensional (2D) imaging with doppler assessment by color and continuous wave doppler done to know the site of 
flow turbulence and quantification of gradients across AMB. Trans-esophageal echocardiography (TEE) confirmed the Trans-thoracic echocardiography (TTE) findings. Right and leftheart catheterization was carried out in all patients. Both Right ventricle and Left ventricle outflow gradients were recorded. Pull back pressure gradient recorded from the pulmonary artery to the right ventricular outflow to the right ventricular inflow. Right ventricular angiography was done in both antero-posterior and lateral view and left ventricular angiography done in Left anterior oblique view.
All surgically corrected patients were followed up at 1, 3, 6 months and then annually. At each visit, they were evaluated by 2D imaging with doppler assessment by color and continuous wave doppler done to know the pressure gradients across AMB.

\section{Statistical Analysis}

Age and follow-up intervals are expressed as median and range. Group data are presented as the mean value \pm standard deviation. The relationship among parameters was analyzed using the Spearman nonparametric test. For each of the analyses, a $p$ value of $<0.05$ was considered significant.

\section{Results}

Table 1: Clinical characteristics of DCRV patients.

\begin{tabular}{|c|c|c|c|c|c|c|c|c|c|}
\hline Patients & Age & Sex & Complaints & $\begin{array}{l}\text { Known Heart } \\
\text { Disease }\end{array}$ & BP & PR & Murmur & ECG & Chest X Ray \\
\hline 1 & 26 & $\mathrm{~F}$ & $\begin{array}{l}\text { Dyspnoea, Chest Pain } \\
\text { \& Palpitations-5 Years }\end{array}$ & PM-VSD & $110 / 70$ & 78 & $\begin{array}{l}\text { Grade IV/VI } \\
\text { ESM }\end{array}$ & $\begin{array}{l}\text { RAD, RVH, } \\
\text { RAE }\end{array}$ & Mild Cardiomegaly \\
\hline 2 & 38 & $\mathrm{~F}$ & $\begin{array}{c}\text { Dyspnoea, Palpitations } \\
-1 \text { Year }\end{array}$ & & $130 / 80$ & 88 & $\begin{array}{l}\text { Grade IV/VI } \\
\text { ESM }\end{array}$ & $\begin{array}{l}\text { RAD, RVH, } \\
\text { Incomplete } \\
\text { RBBB, RAE }\end{array}$ & Mild Cardiomegaly \\
\hline 3 & 30 & $\mathrm{~F}$ & $\begin{array}{l}\text { Dyspnoea, Fatigue, } \\
\text { Palpitations- 1Year }\end{array}$ & PM-VSD & $128 / 70$ & 89 & $\begin{array}{l}\text { Grade IV/VI } \\
\text { ESM }\end{array}$ & $\begin{array}{l}\text { RAD, RVH, } \\
\text { Complete } \\
\text { RBBB, RAE }\end{array}$ & Mild Cardiomegaly \\
\hline 4 & 29 & M & $\begin{array}{l}\text { Asymptomatic- } \\
\text { Follow-Up }\end{array}$ & $\begin{array}{l}\text { PM-VSD } \\
\text { (Operated) }\end{array}$ & $127 / 70$ & 98 & $\begin{array}{l}\text { Grade II/VI } \\
\text { ESM }\end{array}$ & Normal & Normal \\
\hline 5 & 28 & M & Palpitations-7 months & PM-VSD & $110 / 70$ & 78 & $\begin{array}{l}\text { Grade II/VI } \\
\text { ESM }\end{array}$ & Normal & Normal \\
\hline 6 & 32 & M & $\begin{array}{c}\text { Palpitations, one } \\
\text { episode syncope-1 } \\
\text { year }\end{array}$ & PM-VSD & & & $\begin{array}{l}\text { Grade IV/VI } \\
\text { ESM }\end{array}$ & $\begin{array}{l}\text { RAD, RVH, } \\
\text { Incomplete } \\
\text { RBBB, RAE }\end{array}$ & Mild Cardiomegaly \\
\hline 7 & 24 & M & $\begin{array}{c}\text { Dyspnoe, fatigue- }-5 \\
\text { months }\end{array}$ & PM-VSD & $100 / 68$ & 92 & $\begin{array}{l}\text { Grade IV/VI } \\
\text { ESM }\end{array}$ & $\begin{array}{l}\text { RAD, RVH, } \\
\text { RAE }\end{array}$ & Mild Cardiomegaly \\
\hline 8 & 21 & M & $\begin{array}{l}\text { Dyspnoea, chest pain } \\
\text { and palpitations-3 } \\
\text { months }\end{array}$ & PM-VSD & $112 / 76$ & 76 & $\begin{array}{l}\text { Grade IV/VI } \\
\text { ESM }\end{array}$ & RAD, RVH & Mild Cardiomegaly \\
\hline 9 & 18 & M & $\begin{array}{c}\text { Dyspnoea on } \\
\text { exertion-6 months }\end{array}$ & PM-VSD & $110 / 82$ & 86 & $\begin{array}{l}\text { Grade IV/VI } \\
\text { ESM }\end{array}$ & $\begin{array}{l}\text { RAD, RVH, } \\
\text { Incomplete } \\
\text { RBBB, RAE }\end{array}$ & Mild Cardiomegaly \\
\hline 10 & 31 & $\mathrm{~F}$ & $\begin{array}{l}\text { Dyspnoea, one episode } \\
\text { suncope-1 year }\end{array}$ & PM-VSD & $124 / 86$ & 84 & $\begin{array}{c}\text { Grade IV/VI } \\
\text { ESM }\end{array}$ & RAD,RVH,RAE & Mild Cardiomegaly \\
\hline
\end{tabular}

In this study, mean age was 28 years, four patients were female and six were male. Seven patients complained of exertional dyspnea f NYHA class II and more (Patient 1, 2, 3, 7, 8, 9, \& 10), six patients with palpitations (Patient 1, 2, 3, 5, 6 \& 8), two patients with chest pain (Patient 1,8), two patients with syncope (Patient 6,10) and easy fatigability (Patient 3, 7); Patients with corresponding numbers can be found on Table 1 . Nine patients had a history of a known heart disease since childhood (PM-VSD) with one patient being operated at the age 9 years (Patient 4) and one patient had isolated DCRV. On physical examination, all patients showed a loud, harsh, ejection systolic murmur (ESM) of variable grade at the second and third left intercostal space. Chest $\mathrm{X}$-ray showed mild cardiomegaly in three patients and remaining patients had normal chest X-rays. Electrocardiogram (ECG) showed right axis deviation (RAD), right ventricular hypertrophy (RVH) and right atrial enlargement (RAE) in three DCRV patients, with normal in two patients. Clinical characteristics of all patients are shown in Table 1. 


\section{Journal of Cardiology \& Cardiovascular Therapy}

All patients underwent detailed echocardiography, The pulmonic valve was normal in all patients. Cardiac catheterization was done in all patients, Figure 1 showing cath of Patient 1. Figure
1-3 showing echo findings of patient 1,2 \& 3 . Echocardiography and catheterization findings are shown in Table 2.
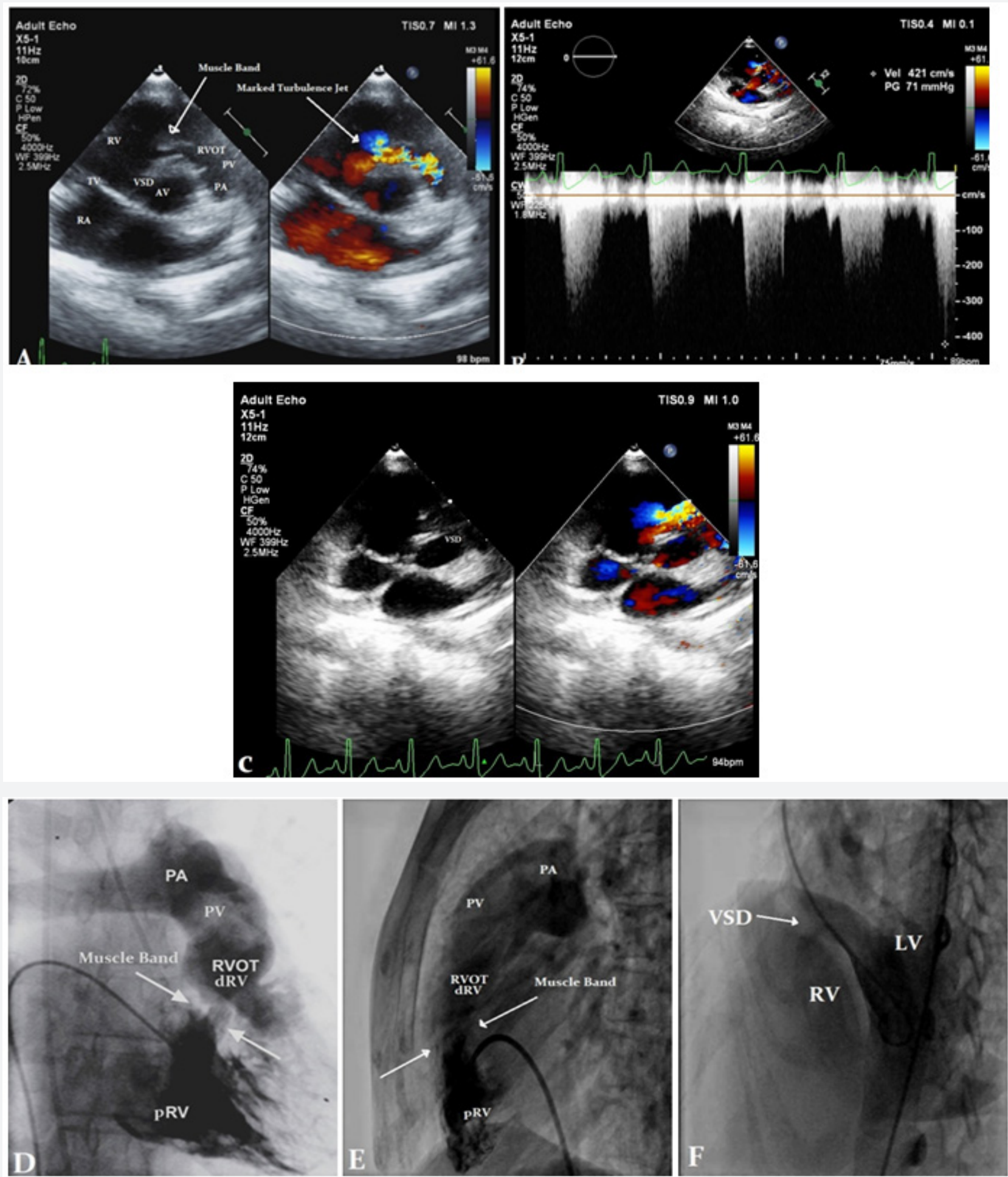

Figure 1: TTE of Patient 1 showing AMB in the RVOT ( arrow) with PM-VSD (1A, 1B \& 1C). Right ventricular angiography in PA view (1D) and lateral view (1E) showed presence of muscle band in RVOT dividing into proximal and distal chambers, left ventricular angiography showed PM-VSD (1F). 




Figure 2: TTE of patient 2 showing AMB in the RVOT ( arrow) with grade II TR (2A, 2B \& 2C).

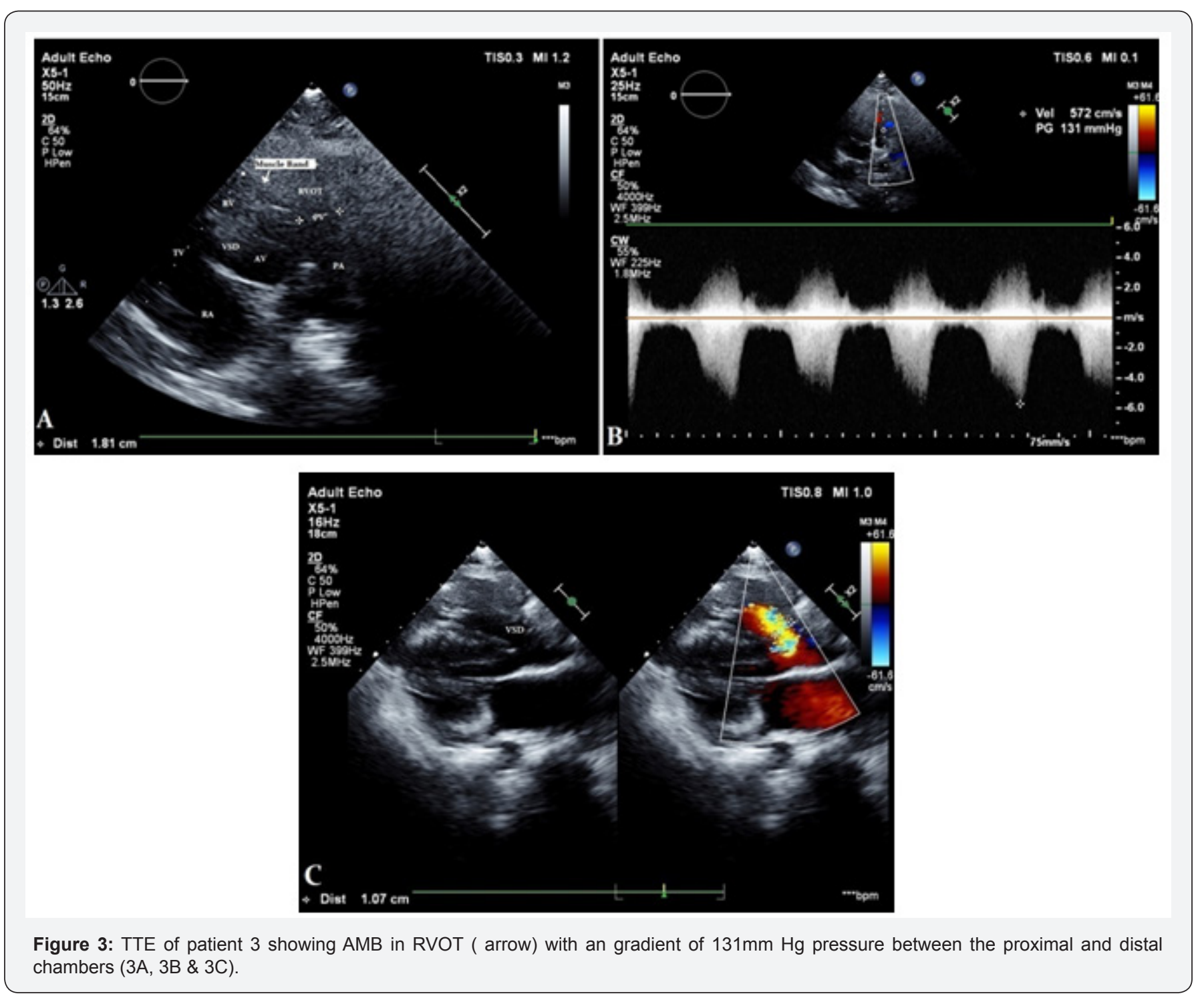


Table 2: Echocardiography and Hemodynamic data in DCRV patients.

\begin{tabular}{|c|c|c|c|c|c|c|c|c|c|}
\hline \multirow{2}{*}{ Patients } & \multicolumn{2}{|c|}{ Gradient } & \multirow{2}{*}{$\begin{array}{l}\text { Shunt size } \\
\text { (mm) }\end{array}$} & \multirow{2}{*}{$\begin{array}{l}\text { LV pressure } \\
\text { (mmHg) }\end{array}$} & \multirow{2}{*}{$\begin{array}{c}\text { RV inflow } \\
\text { pressure (mmHg) }\end{array}$} & \multirow{2}{*}{$\begin{array}{c}\text { RV outflow } \\
\text { pressure (mmHg) }\end{array}$} & \multirow{2}{*}{$\begin{array}{c}\text { PAP } \\
(\mathrm{mmHg})\end{array}$} & \multirow{2}{*}{$\mathrm{QP} / \mathrm{QS}$} & \multirow{2}{*}{ Surgery } \\
\hline & Echo & Cath & & & & & & & \\
\hline 1 & 71 & 80 & 4 & 110 & 102 & 20 & 22 & 1.31 & Yes \\
\hline 2 & 72 & 81 & - & 130 & 101 & 26 & 20 & - & Yes \\
\hline 3 & 130 & 138 & 5 & 128 & 154 & 16 & 16 & 1.51 & Yes \\
\hline 4 & 15 & 16 & - & 127 & 34 & 18 & 22 & - & No \\
\hline 5 & 9 & 7 & 4 & 116 & 32 & 25 & 25 & 2.1 & Yes \\
\hline 6 & 46 & 22 & 7 & 88 & 40 & 21 & 46 & 1.4 & Yes \\
\hline 7 & 59 & 61 & 5 & 121 & 96 & 41 & 42 & 1.3 & Yes \\
\hline 8 & 81 & 97 & 22 & 124 & 120 & 30 & 30 & 2.1 & Yes \\
\hline 9 & 88 & 96 & 20 & 94 & 106 & 16 & 18 & 2.1 & Yes \\
\hline 10 & 64 & 92 & 12 & 110 & 110 & 20 & 21 & 1.9 & Yes \\
\hline Mean & $63.5 \pm 32.1$ & $69.0 \pm 39.4$ & $9.87 \pm 8.0$ & $114.8 \pm 19.4$ & $89.5 \pm 42.1$ & $23.3 \pm 7.8$ & $26.2 \pm 12.1$ & $1.7 \pm 0.8$ & \\
\hline
\end{tabular}

Nine cases were associated with PM-VSD. Surgical correction was carried out for 9 DCRV patients, in eight patients where the pressure gradient across AMB was greater than $20 \mathrm{mmHg}$ and one patient with significant VSD (Qp/Qs $\geq 2.1$ ) (Patient 5). Surgery consisted of a patch closure of the VSD and resection of the AMB through the right atriotomy and pulmonary arteriotomy. Recovery was uneventful with no significant residual gradient across the RV on follow-up echocardiography. All the symptoms disappeared post surgery. In operated DCRV patients, postoperative echocardiograms showed that the pressure gradient across the $\mathrm{AMB}$ in the right ventricle was significantly decreased from $63.5 \pm 14.1 \mathrm{mmHg}$ preoperatively to $10.0 \pm 5.0 \mathrm{mmHg}$ postoperatively $(\mathrm{p}<0.05)$.

\section{Discussion}

Double chambered right ventricle (DCRV) is a rare congenital anomaly in which right ventricle (RV) is divided into two chambers by AMB (anomalous muscle band), a proximal high-pressure and distal low pressure chamber. The prevalence of DCRV in adults has not yet been studied, and the literature only contains a few cases of this disease that were diagnosed in adulthood [6].

It usually presents in childhood and adolescence with most reported cases in patients less than 20 years old. Occasionally, however, patients can present with this condition in adulthood $[5,7]$. The genesis of AMB still not known, but there are various mechanisms have been postulated. These are superior displacement of the septal marginal trabecula (moderator band) has been proposed, particularly in association with a VSD, and flow turbulence in the RVOT [8]. This flow turbulence may trigger abnormal hypertrophy of the moderator band leading to DCRV. This might elucidate the concomitant association between DCRV and VSD $[6,9]$.
DCRV is exceptionally rare as an isolated anomaly [10]. Most commonly it is associated with a membranous type VSD3, the other coexisting lesions include pulmonary stenosis, subaortic stenosis, DORV, TOF, TAPVC/PAPVC, TGA, PA with intact IVS and Ebsteins anomaly [11]. In our study, three cases were associated with VSD (PM-VSD) and one had isolated DCRV.

TTE is an important diagnostic tool in DCRV supplemented by TEE for assessing and quantifying severity of RVOT obstruction. Sometimes DCRV may be missed in patients with obesity and COPD. DCRV should be suspected in ECHO if RV hypertrophy is present in absence of infundibular hypertrophy or valvular pulmonary stenosis [4]. With the introduction of contrast computed tomography and MRI, exact anatomy of RVOT obstruction can be identified.

Surgical intervention is indicated in symptomatic patients or in asymptomatic patients where the peak gradient exceed $20 \mathrm{~mm}$ Hg. In other institute, a cut off of $40 \mathrm{~mm}$ Hg gradient across RVOT was taken for surgical intervention in asymptomatic patients but in our institute, pressure gradient of $>20 \mathrm{~mm} \mathrm{Hg}$ was considered for surgery. The surgical repair of DCRV consists of resection of the AMB with VSD patch closure. According to Oliver et al. [6] a mild right mid ventricular obstruction shows a fast rate of progression in adolescents and young adults. A right ventricular outflow tract obstruction in DCRV is likely to progress, and eventually lead to the patients becoming symptomatic. There is less chance of recurrence of RVOT obstruction following successful surgery, although cases with recurrent obstruction have been described [12].

In our study, no significant increase of the RVOT pressure gradient was recorded at short-term follow-up. In patients who are unfit for surgery, percutaneous alcohol ablation of the conal 
branch from the right coronary artery and the use of balloon dilatation can be attempted [3].

\section{Conclusion}

DCRV has been reported as a rare disease in adults. Consequently, number of cases are missed and not diagnosed. Careful evaluation of DCRV by echocardiography including TEE is necessary, especially in patients with VSD. These patients should be treated surgically, because the obstruction is progressive and ends in heart failure.

\section{References}

1. Hoffman P, Wojcik AW, Rozanski J, Siudalska H, Jakubowska E, et al. (2004) The role of echocardiography in diagnosing double chambered right ventricle in adults. Heart 90(7): 789-793.

2. McElhinney DB, Chatterjee KM, Reddy VM (2000) Double-chambered right ventricle presenting in adulthood. Ann Thorac Surg 70(1): 124127.

3. Thomas BM (2007) Adult congenital heart disease: right ventricular outflow tract lesions. Circulation 115(14): 1933-1947.

4. Cil E, Saraclar M, Ozkutlu S, Ozme S, Bilgic A, et al. (1995) Doublechambered right ventricle experience with 52 cases. Int J Cardiol 50(1): 19-29.
5. Lascano ME, Schaad MS, Moodie DS, Murphy D (2001) Difficulty in diagnosing double-chambered right ventricle in adults. Am J Cardiol 88(7): 816-819.

6. Oliver JM, Garrido A, González A, Benito F, Mateos M, et al. (2003) Rapid progression of mid ventricular obstruction in adults with doublechambered right ventricle. J Thorac Cardiovasc Surg 126(3): 711-717.

7. Doff B, Chatterjee KM, Mohan V (2000) Double-chambered right ventricle presenting in adulthood. Ann Thorac Surg 70(1): 124-127.

8. Wong PC, Sanders SP, Jonas RA, Colan SD, Parness IA, et al. (1991) Pulmonary valve-moderator band distance and association with development of double-chambered right ventricle. Am J Cardiol 68(17): 1681-1686.

9. Kottayil BP, Dharan BS, Pillai VV, Panicker VT, Gopalakrishnan SK, et al. (2011) Surgical repair of double-chambered right ventricle in adulthood. Asian Cardiovasc Thorac Ann 19(1): 57-60.

10. Park JI, Kim YH, Lee K, Park HK, Park CB (2007) Isolated double chambered right ventricle presenting in adulthood. Int J Cardiol 121(3): e25-e27.

11. Hachiro Y, Takagi N, Koyanagi T, Morikawa M, Abe T (2001) Repair of double-chambered right ventricle: surgical results and long-term follow-up. Ann Thorac Surg 72(5): 1520-1522.

12. Moran AM, Hornberger LK, Jonas RA, Keane JF (1998) Development of a double-chambered right ventricle after repair of tetralogy of fallot. J Am Coll Cardiol 31(5): 1127-1133.

\begin{tabular}{|l|}
\hline \multicolumn{1}{|c|}{ Your next submission with Juniper Publishers } \\
- will reach you the below assets \\
- Swift Peer Review \\
- Reprints availability \\
- E-prints Service \\
- Manuscript Podcast for convenient understanding \\
- Global attainment for your research \\
- Manuscript accessibility in different formats \\
( Pdf, E-pub, Full Text, Audio) \\
- Unceasing customer service \\
Track the below URL for one-step submission \\
https://juniperpublishers.com/online-submission.php \\
\hline
\end{tabular}

